\title{
Consumer Buying Behaviour towards Fashion Apparels- A Case of Delhi
}

\author{
Deepali Saluja ${ }^{1}$ \\ ${ }^{I}$ (Banarsidas Chandiwala Institute of Professional Studies, Dwarka, New Delhi, India)
}

\begin{abstract}
Indian markets have been very popular in fashion and especiallywhen it comes to Delhi. It is not only a metropolitan city but a fashion hub too. Delhi is the state where international designers approach for organising their fashion shows and introduce international brands. They design as per the Indian preference. India is a country of the mix of the different culture and each consumer has its own choice and preference.The youth in every segment prefer buying fashion apparels in every season or festivals.This study was conducted to find out the Consumer Buying Behavior Regarding Fashion Apparels in Delhi. The purpose is also to study how consumer behavior for apparel is influenced by factors like monthly income, gender and peer influence.The survey conducted onDelhites shows that the consumers prefer shopping mostly with their friends and family members. They are influenced by their choices of their friends, family members, celebrities, magazines etc. Quality, comfort, brand are the main criteria's which impact their buying behavior towards fashion apparels. The study shows that the age, gender, education and occupation do not have any impact on buying behaviour of consumers. Finally, the survey shows that Delhi consumers have positive attitude towards fashion apparel brands.
\end{abstract}

Keywords- branded, buying behaviour, casual wear, ethnic.

\section{INTRODUCTION}

India is changing with the latest trends in apparels. India is also known for its fashion as well as. Ethnic and traditional apparels have been an identity of India since long. But now-a-days fashion apparels have changed the scenario of Indian market.

Modern consumption patterns have changed and evolved where consumers are well aware of fashion trends and updates are easily available to consumers for all segment through different media channels. This has changed consumers motivation behind their fashion consumption as well, some uses fashion as a means of presenting themselves to the society at large.

Fashion is a dynamic phenomenon which changes with time; irrespective of whether it is a garment, cosmetics or jewellery, but to define how fashion has changed. Every year a bewildering array of styles are prepared all over the world and replaced the year after with new ones. Fashion clothing industry is completely dependent on constant ideas and new expectations of the youth.

\section{OBJECTIVE OF THE STUdY}

- To study the Indian apparel market in terms of market size and growth, focusing on men's apparel market, women's apparel market, boys' and girls' apparel market.

- $\quad$ To study the demographic, psychological and socio-economic factors which have influence the consumer purchase behavior for apparel

- To study how consumer behavior for apparel is influenced by factors like monthly income, gender and peer influence.

Hypothesis

- $\quad \mathrm{H}_{01}$ : Gender has no impact on purchasing power of consumer towards fashion apparels.

- $\quad \mathrm{H}_{02}$ : Education qualification has no impact on purchasing power of consumer towards fashion apparels.

- $\mathrm{H}_{03}$ : Occupation has no impact on purchasing power of consumer towards fashion apparels. 
- $\quad \mathrm{H}_{04}$ : Monthly income no impact on purchasing power of consumer towards fashion apparels.

\section{LITERATURE REVIEW}

Jenni Romaneiuk (2013) the results showed a positive relationship, where those with a higher buying frequency and a higher share of category requirements are more likely to give brand associations. The findings also showed that share of category requirements was a greater driver of brand association responses than buying frequencyConsumer behavior which was earlier termed as 'overt behavior' is a continuous consumption process related to pre-purchase, purchase and post purchase issues. This refers to the physical action of consumers that can be directly observed and measured by others. Joergens (2006)Niinimaki (2011) Although there is a demand of fashion clothes, it is not a viable level given the rate at which they are selling. According to Michael R.Solomon, \& Nancy J.Rabolt (2004), consumer behavior is the study of the processes involved when individuals or groups, select purchase, use or dispose of products, services, ideas or experiences to satisfy needs and desires. According to Frank R.Kardes (2002), consumer behavior is the study of human or consumer responds to products, services and the marketing of products and services. The concept of consumer behavior is that mostly people buy products not for what they do but for what they stand for. Sproles and Kendall(1986) established a model to conceptualize consumer decision making behavior with eight consumer mental orientation variables viz. perfectionism consciousness, brand consciousness, novelty and fashion consciousness, impulsive and careless consumer, confused by over choice consumer, habitual and brand loyal consumer, recreational and hedonic shopping consciousness and price and value consciousness. Park J.H and Lennon, S.J (2004) in their study on television apparel shopping and impulse buying found that there is a positive relationship between impulse buying and television exposure.. Kassarjian (1971) states that consumer behavior researchers must develop their own definitions and design their instruments to measure the personality variables that go into the purchase decision. This study developed apparel buying behavior model on the basis of five dimensions, namely consumer characteristics, reference groups, store attributes, promotion and product attributes. All these dimensions are created based on the various research studies on the consumer behavior and also through the opinion of various experts from the industry and academic institutions.

\section{RESEARCH METHODOLOGY}

The research involved collection of both primary data and secondary data. A structured questionnaire has been designed to collect the primary data. The secondary data has been obtained from various journals and websites. The data has been collected from different parts of Delhi from 100 respondents

Statistical tools are used for the analysis of the data collected using questionnaire. Chi-square test had been used to find out the internal consistency between the multiple measurements of a variable in a questionnaire.. The SPSS software is used to assemble and analyze the data and to apply testes on the sample collected. First, the chisquare test was applied. If the value is greater than 0.05 then the null hypothesis is accepted.

\section{DATA ANALYSIS AND INTERPRETATION}

TABLE I. Demographic Profile

\begin{tabular}{|l|l|l|l|}
\hline Variable & Characteristics & Frequency & Percentage \\
\hline Gender & Male & 45 & 45.0 \\
\cline { 2 - 4 } & Female & 55 & 55.0 \\
\hline \multirow{5}{*}{ Education } & $10+2$ or below & 21 & 21.0 \\
\cline { 2 - 4 } & Bachelor's degree & 51 & 51.0 \\
\cline { 2 - 4 } & Master's degree & 16 & 16.0 \\
\cline { 2 - 4 } & Others & 12 & 12.0 \\
\hline \multirow{2}{*}{ Occupation } & Student & 3 & 2.0 \\
\cline { 2 - 4 } & Private & 44 & 44.0 \\
\hline
\end{tabular}


IOSR Journal of Business and Management (IOSR-JBM)

e-ISSN: 2278-487X, p-ISSN: 2319-7668

\begin{tabular}{|l|l|l|l|}
\hline \multirow{4}{*}{ Monthly income } & Government & 27 & 27.0 \\
\cline { 2 - 4 } & Business & 25 & 25.0 \\
\cline { 2 - 4 } & & & 30.0 \\
\cline { 2 - 4 } & $30000-30000$ & 30 & 30.0 \\
\cline { 2 - 4 } & $40000-50000$ & 30 & 20.0 \\
\cline { 2 - 4 } & Above 50000 & 20 & 20.0 \\
\hline
\end{tabular}

The null and alternative hypotheses for Chi-square test are:

- $\mathrm{H}_{01}$ :Gender has no impact on consumer buying behavior regarding fashion apparels.

- H02: Age has no impact on consumer buying behavior regarding fashion apparels.

- $\mathrm{H}_{03}$ : Occupation has no impact on consumer buying behavior regarding fashion apparels.

- $\mathrm{H}_{04}$ : Income level has no impact on consumer buying behavior regarding fashion apparels.

- $\mathrm{H}_{05}$ : Education has no impact on consumer buying behavior regarding fashion apparels.

TABLE II. Chi- Squaretest Forgender and Attitude Towardsfashion Apparels

Case Processing Summary

\begin{tabular}{|c|c|c|c|c|c|c|}
\hline & \multicolumn{6}{|c|}{ Cases } \\
\hline & \multicolumn{2}{|c|}{ Valid } & \multicolumn{2}{|c|}{ Missing } & \multicolumn{2}{|c|}{ Total } \\
\hline & $\mathrm{N}$ & Percent & $\mathrm{N}$ & Percent & $\mathrm{N}$ & Percent \\
\hline $\begin{array}{l}\text { Avgpurchasingpower } \\
\text { gender }\end{array}$ & 100 & $100.0 \%$ & 0 & $.0 \%$ & 100 & $100.0 \%$ \\
\hline
\end{tabular}

Chi-Square Tests

\begin{tabular}{|c|c|c|c|c|c|}
\hline & Value & df & $\begin{array}{l}\text { Asymp. Sig. (2- } \\
\text { sided) }\end{array}$ & $\begin{array}{|lll|}\begin{array}{l}\text { Exact } \\
\text { sided })\end{array} & \text { Sig. (2- } \\
\end{array}$ & \begin{tabular}{|l}
$\begin{array}{l}\text { Exact Sig. (1- } \\
\text { sided) }\end{array}$ \\
\end{tabular} \\
\hline Pearson Chi-Square & $.587^{\mathrm{a}}$ & 1 & .444 & & \\
\hline Continuity Correction ${ }^{\mathrm{b}}$ & .031 & 1 & .860 & & \\
\hline Likelihood Ratio & .588 & 1 & .443 & & \\
\hline Fisher's Exact Test & & & & .587 & .424 \\
\hline $\begin{array}{l}\text { Linear-by-Linear } \\
\text { Association }\end{array}$ & .581 & 1 & .446 & & \\
\hline $\mathrm{N}$ of Valid Cases & 100 & & & & \\
\hline
\end{tabular}

The value of Pearson Chi-square is 0.444 .From the table, it can be seen that value is more than 0.05 , hence we can't reject the null and we accept the null by stating that gender has no impact on attitude towards fashion apparels.

TABLE III. Chi-Square Test for Education Qualification and Attitude Towards Fashion Apparels

Chi-Square Tests

\begin{tabular}{|l|l|l|l|}
\hline & Value & df & $\begin{array}{l}\text { Asymp. Sig. } \\
(2-\text {-sided })\end{array}$ \\
\hline Pearson Chi-Square & $3.815^{\mathrm{a}}$ & 3 & .282 \\
\hline Likelihood Ratio & 4.724 & 3 & .193 \\
\hline $\begin{array}{l}\text { Linear-by-Linear } \\
\text { Association }\end{array}$ & .967 & 1 & .325 \\
\hline N of Valid Cases & 100 & & \\
\hline
\end{tabular}


Chi-Square Tests

\begin{tabular}{|l|l|l|l|}
\hline & Value & df & $\begin{array}{l}\text { Asymp. Sig. } \\
(2-\text {-sided })\end{array}$ \\
\hline Pearson Chi-Square & $3.815^{\mathrm{a}}$ & 3 & .282 \\
\hline Likelihood Ratio & 4.724 & 3 & .193 \\
\hline $\begin{array}{l}\text { Linear-by-Linear } \\
\text { Association }\end{array}$ & .967 & 1 & .325 \\
\hline N of Valid Cases & 100 & & \\
\hline
\end{tabular}

The value of Pearson Chi-square is 3.815 . From the table, it can be seen that value is more than 0.05 ,hnce we can't reject the null and we accept the null by stating that education qualification has no impact on attitude towards fashion apparels. Chi square was applied as test of significance at alpha $=0.05$, the result are as follows:

TABLE IV. Chi- Square Test for Occupation and Attitude Towards Fashion Apparels Chi-Square Tests

\begin{tabular}{|l|l|l|l|}
\hline & Value & df & $\begin{array}{l}\text { Asymp. Sig. (2- } \\
\text { sided) }\end{array}$ \\
\hline Pearson Chi-Square & $3.467^{\mathrm{a}}$ & 3 & .325 \\
\hline Likelihood Ratio & 4.292 & 3 & .232 \\
\hline $\begin{array}{l}\text { Linear-by-Linear } \\
\text { Association }\end{array}$ & 3.301 & 1 & .069 \\
\hline N of Valid Cases & 100 & & \\
\hline
\end{tabular}

The value of Pearson Chi-square is 0.325 From the table , it can be seen that value is more than 0.05 , hnce we can't reject the null and we accept the null by stating that occupation has no impact on attitude towards fashion apparels. Chi square was applied as test of significance at alpha $=0.05$, the result are as follows:

TABLE V. Chi-Square for Monthly Income and Attitude Towards Fashion Apparels

\begin{tabular}{|l|l|l|l|}
\multicolumn{5}{c|}{ Chi-Square Tests } \\
\hline & Value & df & $\begin{array}{l}\text { Asymp. Sig. (2- } \\
\text { sided) }\end{array}$ \\
\hline Pearson Chi-Square & $1.543^{\mathrm{a}}$ & 3 & .672 \\
\hline Likelihood Ratio & 2.337 & 3 & .505 \\
\hline $\begin{array}{l}\text { Linear-by-Linear } \\
\text { Association }\end{array}$ & 1.343 & 1 & .246 \\
\hline N of Valid Cases & 100 & & \\
\hline
\end{tabular}

The value of Pearson Chi-square is 0.672 From the table, it can be seen that value is more than 0.05 , hnce we can't reject the null and we accept the null by stating that monthly income has no impact on attitude towards fashion apparels.

\section{FINDINGS}

The study shows that there were significant differences between the gender, education, monthly income and occupation. For each of our relevant demographics factors the result found mainly differences concerning the price of fashion apparels and the various other factors such as quality, comfort and also the attributes of a store which affected their purchase intention

Our findings show that consumers agree with the fact that they were satisfied by fashion apparels they bought and we found that satisfaction was positively correlated (even if the chi-square Pearson coefficient is more than 0.05 hence, we can accept the null, with most of our statements linked to the quality of the fashion apparels, that they have a great impact on their purchasing power. 
These findings are relevant because the more people in today's world enjoy shopping and the more they are satisfied about their previous purchases the more they are willing to repeat purchases that can lead to brand loyalty toward the brands.

The study shows that the consumer is more tend to ethnic opting the other segments. If the frequency of purchase is high and if you are satisfied by these previous purchases it is logical that the purchase intention in a near future is high because you develop positive attitudes and behavior towards these products so our results confirm what was found in the previous studies and survey about this topic. So we can accept our hypothesis that assumes that satisfaction and purchasing power of consumer are positively related and satisfaction towards fashion apparels.

\section{CONCLUSIONS}

The purchase intention of consumers is influenced by attitude variables. The consumers enjoy shopping mostly with their friends and family members. They are influenced by their friends, family members, celebrities, magazines etc. Quality, comfort, brand are the main criteria's which effect their buying behavior towards fashion apparels. Even all the demographic factors like gender, age, occupation and monthly income don't have any impact on buying behaviour of consumers towards fashion apparels.

\section{REFERENCES}

[1] C. D'Souza and A.J. Gilmore, "Male eco-fashion: a market reality", International Journal of Consumer Studies, 39(1), $2015,35-42$.

[2] K. B. Gurunathan and M. Krishnakumar, "Factors influencing apparel buying behavior in India: A measurement model, 2(3), 2013, 218224.

[3] A. Chakrapani, "Consumer behavior and preference of Indian consumers towards fashion apparel purchase", 4(8), 2014, 1-15.

[4] F. R. Kardes, Consumer behavior, (Pearson Education International, 2002), 325.

[5] J. Paul and J. Rana, "Consumer behavior and purchase intention for organic food" , Journal of Consumer Marketing, 29(6), 2012, 412 422.

[6] M.R. Solomon and N.J. Rabolt, Business \& Economics (Prentice Hall, 2004), 542.

[7] J.H. Park and S.J. Lenon, "Television apparel Shopping: Impulse Buying and Parasocial interaction, Clothing \& Textiles", The Research Journal, 22(3), 2004, 135-144.

[8] http://www.wsj.com/public/page/news-fashion-style-industry.html.

[9] http://www.emeraldinsight.com.

[10] http://seminarprojects.com/thread-consumer-buying-behavior-towards-branded-apparels-in-kanpur-city-report\#ixzz42bzhgydr. 